\title{
Understanding Post Contractual Turbulence in Public Private Partnerships: Themes and Issues
}

\author{
Moses Onyoin
}

\section{University of Hull, United Kingdom}

\begin{abstract}
Although complex realities of governing Public Private Partnerships (PPPs) at the post contractual phase are emerging as major foundations of discord that threatens PPPs sustainability in developing countries (DCs), the nascent nature of the model's application in most DCs has meant that the specific issues of concern remain obscure and scattered. Using the concept of governance as an orienting lens, an intensive analysis of one of the pioneer PPP projects in the electricity sector in Sub-Saharan Africa is undertaken to explore the main issues. The evidence is drawn from transcripts of interviews with policy, regulative, and operative actors directly involved with and/or familiar with the project. These are supplemented by a review of exclusively accessed and publicly available documents. The findings underscore the primacy of eight governance issues that are organised in three thematic areas including; the roles and responsibilities of actors, regulatory and contractual control, and emergent and complex external stakeholder behaviour. The findings essentially suggest that at the post contractual phase, (a) PPP will be challenged by context specific realities related to how the sector is organized, the prevailing sources of authority, and end user behaviour, (b) PPP agreements are incapable of precisely providing for all emergent realities thus require adaptation and/or complementation, and (c) demonstrate that responses need to be deliberately concerted as well as inclusive of context-relevant actors to guard against a) severely undermining provisions of the existing contract, b) partner (and other external stakeholder) opportunism, and c) counterproductive distortion of balance of power.
\end{abstract}

Keywords: Public Private Partnerships, infrastructure, Africa, governance, postcontract 


\section{Introduction}

The use of the modality of Public Private Partnership (PPP) in the delivery of public services and infrastructure is no longer a brand new phenomenon (Hodge and Greve, 2007; Reeves, 2013; Sheratt et al., 2020). Notwithstanding the varying scopes and depth of adoption, the high proliferation of PPPs can be evidenced across the globe in both developed and developing countries (Appuhami and Perera, 2016; Hodge and Greve, 2007; Jamali, 2004; Reeves, 2013).

Defined broadly as an arrangement where the public sector enters into long-term contractual agreement with private sector entities for the construction or management of public sector infrastructure facilities by the private sector entity, or the provision of services by the private sector entity on behalf of a public sector entity (Grimsey and Lewis, 2002; Bovaird, 2004; Brinkerhoff and Brinkerhoff, 2011), PPPs have gained popularity and iconic status as one of the visible pillars of contemporary public management practices (Hodge and Greve, 2010; Weihe, 2008; World Bank, 2019). The specific rationales for PPP adoption have crisscrossed bounds from fiscal and efficiency considerations (Sheratt et al., 2020; Stafford and Stapleton, 2017), acknowledgement of increasing complexity of public problems (Brinkerhoff and Brinkerhoff, 2011; Sherratt et al., 2020), risk dispersion (Bryson et al., 2017; Grimsey and Lewis, 2002; Velotti et al., 2012), to reflection of ideological shifts as well as a tool for ideological comprise (Saz-Carranza and Longo, 2012; Heuer, 2011; Vurro et al., 2010). As a result, since the early 2000s, many countries have intensified efforts to establish PPP as important framework of public service and infrastructure provision (World Bank, 2018; 2019).

However, with an increased number of projects reaching the implementation phase, the near panacea value of PPPs appears to be challenged by emergent discord endangering their sustainability. Specifically, reports of PPP cancellations and distress are increasing (Marcelo et al., 2017). The World Bank's Private Participation in Infrastructure (PPI) database defines a cancelled PPP project as one in which the private partner has quit a partnership either by selling or transferring its economic interest back to the government before fulfilling the contract terms while a distressed PPP project is when a public sector partner or private sector operator has either requested a contract to be terminated or have requested international arbitration to settle a dispute (Marcelo et al., 2017; World Bank, 2019).

The current PPI database shows that 216 PPP projects in developing countries across the globe were cancelled while 73 projects are distressed, out of 6,907 PPP projects from 1991 to 2018 . These cancellations represent $\$ 62.17$ billion of the $\$ 1.61$ trillion committed investments. While this might appear small, this ought to be understood in the context that in the same period only 194 projects were concluded (World Bank, 2019). In addition, cancellation of projects is of particular concern for developing countries where there are more fiscal constraints. Moreover, when these cancellations occur, disruption in public service provisions occur, discouragement in further private investment is occasioned, and for specific projects may require commitment of public resources on payouts and as well as subsequent high risk premiums (Johnston and Gudergan, 2007; Marcelo et al., 2017).

International Journal of Management and Applied Research, 2021, Vol. 8, No. 1 
The extant research appears to suggest two explanations. First, the situation is associated to the quality of partnerships management and as such to how the partnerships are managed (Sabry, 2015; Saz-Carranza and Longo, 2012). Van Gestel et al. (2014), for instance, note that the complicated governance arrangements of PPPs are at the heart of unpredictable outcomes. In fact, these scholars have been joined by others (Hodge and Greve, 2010) to specifically call for attention to move to the 'second generation' concerns focusing on PPP governance and regulation.

Secondly, attributions have been made to the fundamental character of public private partnerships, particularly, the high levels of complexity that generates contradiction at both formative and operative phases (Sheratt et al., 2020; Trebilcock and Rosenstock, 2015; van den Hurk and Verhoest, 2015). Others attributions connected to the fundamental character are competing institutional logics (Heuer, 2011; Saz-Carranza and Longo, 2012), inherent conflict of interest between partners (Bovaird, 2004), and incompleteness of control instruments, specifically contracts (Johnston and Gudergan, 2007), longevity and task bundling (Boyer, 2016; Van Gestel et al., 2014).

Unfortunately, even though attributions to such fundamental realities of PPP character may suggest high potential for discord and may indeed provide underlying explanation, the trigger issues of concern at the post contractual phase remain largely obscure and scattered in the context of developing countries. This obscurity may be explained by two important realities of PPP phenomenon in developing countries. Firstly, majority of studies related to PPP focus on pre-contractual stage, such as cost of financing the model, value for money, contracts negotiation (Grimsey and Lewis, 2002; Chung, 2009; Appuhami and Perera, 2016). Secondly, the experiences with PPPs at the post contractual phase are still limited and there is a significant disjoint between pre-contract and post-contract project assessments (Sherratt et al., 2020).

In that regard, this paper seeks to foreground the important post contractual PPP issues by answering the following consolidated question: what are the key governance issues at the post contractual PPP phase in developing countries, how can these be organized, and what are their implications for PPP policy, practice and future research. The paper will be of interest to regulators, private sector actors and government agencies as they examine the most appropriate and sustainable manner in which to discharge the public service obligations in the framework of multi sector partnerships.

The rest of this paper is organized as follows. Section two purposively unpacks the notion of governance from an management and public policy perspective as a theoretical frame of reference orienting the analysis of evidence, discussion of finding and shaping the implications. Section three discusses the methods used to collate the evidence and the analysis approach. Section four presents and discusses the findings from analysis of the evidence in the context of available research and notion of governance. Specifically, the section presents and discusses the eight issues in three themes delineated from the analysis. Section five presents the conclusions, important policy and research implications.

International Journal of Management and Applied Research, 2021, Vol. 8, No. 1 


\section{The frame of reference: the notion of governance}

Given that the central concern of this paper is on foregrounding important issues at the post contract phase and that extant assertions that the challenges faced by PPPs are mainly managerial and governance in nature (Saz-Carranza and Longo, 2012; Sheratt et al., 2020; Weihe, 2008), the notion of governance is utilised to orient the investigation. The concept of governance is multifaceted owing to its application in diverse theoretical and research perspectives (Sheratt et al., 2020; Stafford and Stapleton, 2017). Considered 'hardy perennial', in contemporary public policy and public management, governance has nearly been an unquestionable concept in management and public policy sciences (Griffith-Jones and Bhattacharya, 2001). The concepts' multivalency, in particular, underscores its prominence in management sciences and in academic public policy discourse.

In this paper a purposive consideration of the concept is taken from an applied management and public policy perspectives (Hodge and Greve, 2007; Sherratt et al., 2020; Word Bank, 1994) todelineate four major tenets that orient the empirical evidence and analysis.

The first tenet is governance as institutions, methods, and instruments of governing (Stafford and Stapleton, 2017; Weihe, 2008; Vangen et al., 2015). In this regard critical issues from the evidence relating the design and use of a structure and processes that enable actors to direct, coordinate, and allocate resources and coordinate or control activities for the collaboration as a whole and to account for its activities.

The second tenet is governance as the relationship between the government and citizens (Birner and Wittmer, 2006; Brinkerhoff and Brinkerhoff, 2011; Sabry, 2015; Word Bank, 1994). The focus is on delineation of issues in the course of the partnership depicting the nature of ongoing interaction between the government as duty bearer for service provision and a range of stakeholder groupings, including implementing actors and the citizenry as end users. In particular, the issues keen to the role and participation of the different stakeholders on the decision making process.

The third tenet is governance as role of the state (Jamali, 2004; Appuhami and Perera, 2016; Boyer, 2016) the analysis is oriented to the identification of issues keen to the responsibility of PPPs as proxy executor of the role of the state and the emergent issues from the changed role of the state and or public sector actors in the implementation of the partnership.

The fourth tenet is governance as exercise of power (Birner and Wittmer, 2006; SazCarranza and Longo, 2012), and the focus here is on issues relating to the appropriation and application of authority among important actors in the course of the partnership. The figure below further illustrates the orienting facets used to signpost the experiences of actors and the identification of issues from in the courses of the analysis as elaborated in the next section.

International Journal of Management and Applied Research, 2021, Vol. 8, No. 1 
Table 1: Tenets of Governance from Management and Public Policy lens

\begin{tabular}{|l|l|}
\hline $\begin{array}{l}\text { Governance as institutions, methods, and } \\
\text { instruments of governing } \\
\text { Relating the design and use of a structure } \\
\text { and processes that enable actors to direct, } \\
\text { coordinate, and allocate resources and } \\
\text { coordinate or control activities for the } \\
\text { collaboration as a whole and to account for } \\
\text { its activities }\end{array}$ & $\begin{array}{l}\text { Governance as the relationship between } \\
\text { the government and citizens } \\
\text { Depicts the nature of ongoing interaction } \\
\text { between the government as duty bearer for } \\
\text { service provision and a range of stakeholder } \\
\text { groupings, including implementing actors } \\
\text { and the citizenry as end users }\end{array}$ \\
\hline $\begin{array}{l}\text { Governance as the role of the state } \\
\text { Relating to the responsibility of PPPs as } \\
\text { proxy executor of the role of the state and } \\
\text { the emergent issues from the changed role of } \\
\text { the state and or public sector actors in the } \\
\text { implementation of the partnership }\end{array}$ & $\begin{array}{l}\text { Governance as exercise of power } \\
\text { Relating to the appropriation and application } \\
\text { of authority among important actors in the } \\
\text { course of the partnership }\end{array}$ \\
\hline
\end{tabular}

\section{Materials and methods}

The research draws on empirical data from one of the pioneer and largest PPP projects in the electricity sector in sub-Saharan Africa. A 20 year electricity distribution concession in Uganda (in its 13th year at the time of data collection) is utilized as the empirical site. A case study approach is used since PPP is still at its early stage in many developing countries and research investigating its complexity in Uganda is limited. This study adopts Neale et al. (2006) and (Yin, 2011) protocols for preparing a case study. In particular, the electricity distribution concession, between the UMEME Limited and Uganda Electricity Distribution Company Limited, was chosen based on known and distinct characteristics.

This case was selected since (i) it is the first PPP in electricity following the electricity sector reform of the late 1990s and largest PPP in scope and investment in Uganda, (ii) one of the pioneer and largest in the electricity sector in sub-Saharan Africa (World Bank, 2019), (iii) the PPP with the longest post contractual experience in Uganda, (iv) deemed one of the most successful PPPs in sub-Saharan Africa, (v) has overcome many and nationally and internationally publicized challenges to remain operational (World Bank, 2017), and (vi) access to documents and participants could be enabled by first authors connections with some actors and familiarity with the national context.

In regard to the sector, globally the energy has attracted the most private sector participation (World Bank, 2018). Energy accounts for more than 50\% of the current PPI investment across all four infrastructure sectors included in the PPI databaseenergy, water, transport and ICT (World Bank, 2018; 2019) and is thus considered to hold high potential to explore wide ranging experiences.

The data was collated through semi-structured interviews and a review of exclusively availed and publicly available documents. Twenty eight (28) interviews, focused on the current and retrospective post contract experiences, were conducted with individual actors directly involved or familiar with the case study.

International Journal of Management and Applied Research, 2021, Vol. 8, No. 1 
Understanding Post Contractual Turbulence in Public Private Partnerships: Themes and Issues

Table 2: Organisation based categorisation of respondents

\begin{tabular}{lr}
\hline Organisational category & No. of Participants \\
\hline Independent sector regulation & 8 \\
Government departments/ agencies & 14 \\
Local and international consulting organisations & 2 \\
Private sector partnering organisations & 4 \\
\hline
\end{tabular}

The interviewees were drawn from the regulatory agency, government departments and agencies, public and private sector partner organisations, local and international consulting firms through a snowballing technique (Miles and Huberman, 1994). The technique was particularly useful because (a) the post contractual experiences with PPPs in Uganda remain limited and are held within a network of few people, and (b) PPPs are highly regarded as commercially confidential transactions and therefore the discussion of internal operational issues is regarded sensitive. Other PPP scholars studying similar contexts found this technique equally useful (see for example, Chung, 2009; Jamali, 2004; Opawole and Jagboro, 2017). Documentary data was obtained by reviewing reports of the sector regulator, concession agreements, partner's organizations reports, press releases, and media reporting.

The transcripts and sourced documents were uploaded to Qualitative Data Analysis Software (QDAS), NVIVO 12, for analysis. Drawing on the conceptual boundaries of governance reflected in the previous section, the data was analyzed through a code system by means of content analysis (Bernard and Ryan 2010). Specifically, data coding was undertaken in three coding cycles each with separate coding strategy and aim. In the first, a code was created for each observation to develop an elaborate and specific list of observations. In the second, codes were mapped to create a list of issue based categories. In the final cycle, the issues based categories were themed as illustrated in the protocol below.

Figure 1: Interview Analysis Protocol

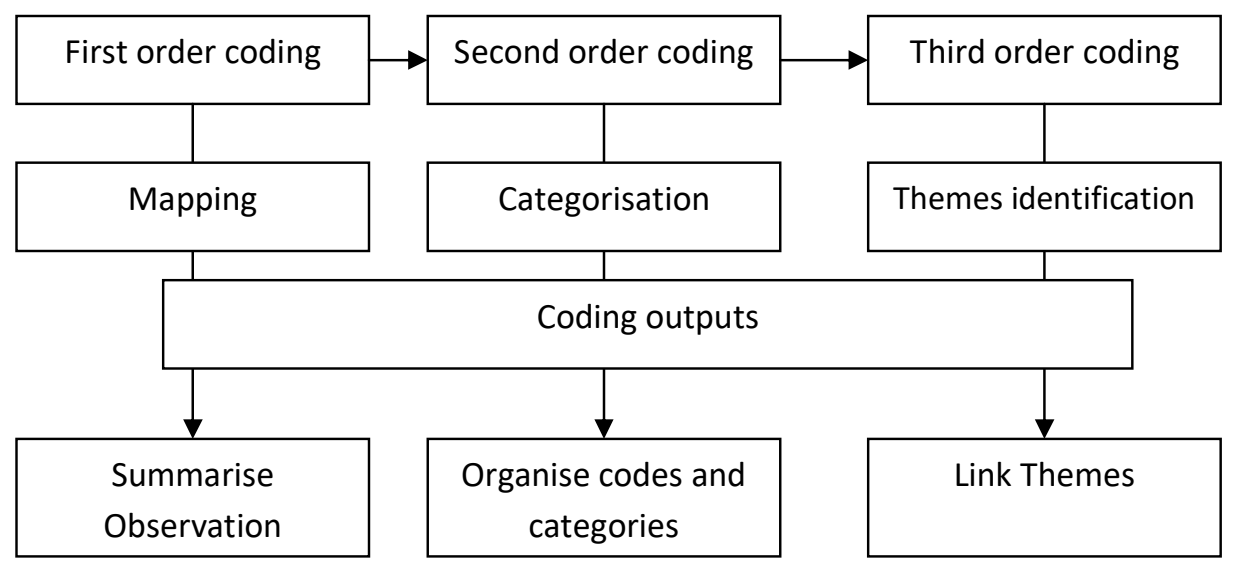

The three major themes and eight issues identified are presented and discussed in the following section.

International Journal of Management and Applied Research, 2021, Vol. 8, No. 1 


\section{Findings and discussions}

The analysis of empirical case evidence reveals the primacy of eight issues. In this section, issues are organized, elaborated, and interpreted in three thematic categories including the roles and responsibilities of actors in the partnership, regulatory and contractual control of the partnership, and stakeholder expectations and perceptions as seen in summary in Table 3 below.

Table 3: Summary of Themes and Issues

\begin{tabular}{|c|c|c|}
\hline Theme & Key Issues & Exemplars \\
\hline \multirow[t]{3}{*}{$\begin{array}{l}\text { Roles and } \\
\text { responsibilities } \\
\text { of actors, } \\
\text { behaviour. }\end{array}$} & $\begin{array}{l}\text { I. } \\
\text { princingreements on the extent of } \\
\text { responsibilities and obligations }\end{array}$ & 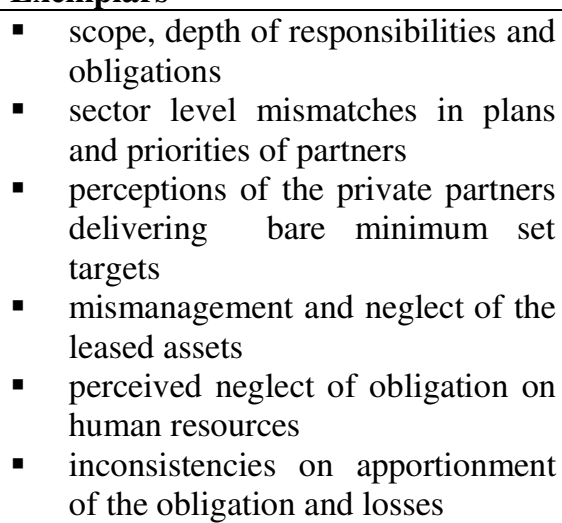 \\
\hline & $\begin{array}{ll}\text { II. } & \text { ambiguity of value chain } \\
\text { actor's responsibility and } \\
\text { obligations. }\end{array}$ & $\begin{array}{l}\text { - inadequacies in the amount of } \\
\text { electricity generated }\end{array}$ \\
\hline & $\begin{array}{l}\text { III. conflict in the identity and role } \\
\text { of the public sector partner }\end{array}$ & 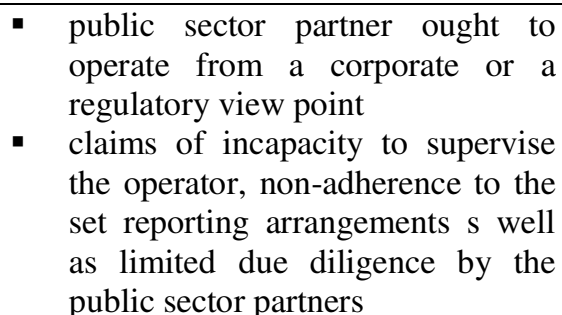 \\
\hline \multirow[t]{3}{*}{$\begin{array}{l}\text { Regulatory } \\
\text { and } \\
\text { contractual } \\
\text { control }\end{array}$} & $\begin{array}{l}\text { I. changes in parameters by } \\
\text { actors in the course of } \\
\text { implementation }\end{array}$ & $\begin{array}{l}\text { - definition, quality, quantity and } \\
\text { pricing of investment made by the } \\
\text { private operator } \\
\text { regulatory changes on performance } \\
\text { targets and expectations }\end{array}$ \\
\hline & $\begin{array}{l}\text { administration of regulatory } \\
\text { processes }\end{array}$ & $\begin{array}{l}\text { - how, when and who conducts the } \\
\text { investment approval and } \\
\text { verification processes } \\
\text { - input to setting electricity tariff }\end{array}$ \\
\hline & $\begin{array}{l}\text { application of parallel } \\
\text { regulatory and contractual } \\
\text { tools of control }\end{array}$ & $\begin{array}{l}\text { - } \begin{array}{l}\text { enactment } \text { or re-enactment of } \\
\text { regulatory rules against the } \\
\text { contract }\end{array} \\
\text { then }\end{array}$ \\
\hline \multirow[t]{2}{*}{$\begin{array}{l}\text { Emergent and } \\
\text { complex } \\
\text { external } \\
\text { stakeholder }\end{array}$} & $\begin{array}{l}\text { differences in political actor's } \\
\text { interests and partnership } \\
\text { interest }\end{array}$ & $\begin{array}{l}\text { - attempts to cause changes to the } \\
\text { agreed commitments, processes } \\
\text { - individual political actor's } \\
\text { directives }\end{array}$ \\
\hline & service end user behaviour & $\begin{array}{l}\text { - a perception of end user being } \\
\text { exploited by the private operator } \\
\text { - payments compliance attitudes } \\
\text { - escalation of complaints }\end{array}$ \\
\hline
\end{tabular}

International Journal of Management and Applied Research, 2021, Vol. 8, No. 1 
In expounding on the themes, in this section, a summary of the evidence illuminating each of the issues is provided followed by an interpretation in the context of extant international research in the perspective of tenets of governance applied in this paper. Except for where a direct reference to a specific empirical context is necessary to provide better clarity of the issue, use of thick descriptions in form of direct quotes and excerpts from documents to illustrate the evidence are intentionally minimize. Instead, sufficient reference to sources is provided.

\subsection{The Roles and Responsibilities of Actors in the Partnership}

The pre-eminence of issues relating to the nature, appropriation and execution of responsibilities across actors is noticeable in the analysis of evidence. Specifically, the individual actor experiences in this case indicate the primacy of three key issues at this stage of the partnership.

First, the presence of emergent disagreements on the extent of principal partner's responsibilities and obligations is foregrounded by different individual actor observations. Particularly, the interview evidence exemplifies that there are, at the operational stage, different views on the scope, depth of responsibilities and obligations that partners bear (Interview 23, 2018), sector level mismatches in plans and priorities of partners (Interview 23, 2018) perceptions of the private partners delivering the bare minimum in the face of opportunity to surpass the set targets (Interview 21, 2018), mismanagement and neglect of the leased assets by the operator and non-compliance with the asset maintained (Interview 28, 2018), perceived neglect of obligation on human resources following the concession agreement (Interview 28, 2018), inconsistencies on apportionment of the obligation and losses that arise from the partnership (Interview 21, 2018), and supposed negation by the private operator to agreed obligations (Interview 28, 2018).

This issue finding reinforces prior observations of similarly different views associated with differences in partner's institutional logic (Ramiah and Reich, 2006; Saz-Carranza and Longo, 2012; Sherratt et al., 2020). Ramiah and Reich (2006) for instance note the inherent difficulty to bridging the different goals, values, and processes of public and private organisations. Klijn and Teisman (2000b) similarly note that, "both parties tend to give priority to their own considerations, which has led to classical principal-agent problem" (p. 88). “.. sticking to one's own narrow interests can lead to very meager results" (p. 93).

In this regard, since individual actors work as agents for the respective public and private sector organizations, the courses of action and the priorities will be influenced by the respective goals, values and processes of the organisations represented. This suggest that the narrow underlying absence of common set of goal, values and interests precipitates the difficulties in reaching common agreements on the course of action and on the priorities of action to be undertaken by the actors representing the different organisational partners in the relationship.

International Journal of Management and Applied Research, 2021, Vol. 8, No. 1 
It is important to note that these difficulties also relate to intricacies of the post contractual phase of the PPPs where it is practically impossible to predict and predetermine all the specifics of future relationship. This is a further suggestion that there is incompleteness in formal agreements to specify details of the course of actions for every future occurrence. In other words, the incompleteness of PPP sets the stage for possible divergences between actors on the course and priorities of action as much it creates room for more innovative approaches to be explored by parties in the partnership. Similarly, the finding suggests partner opportunistic behaviour by way of extending and pursing self-interest within the confines of broadly determined and agreed partnership that scholars (Johnston and Gudergan, 2007; Mouraviev and Kakabadse, 2015) have already identified as a critical challenge for partnerships generally.

Secondly, the evidence reveals the ambiguity of value chain actor's responsibilities and obligations. In this paper the notion of value chain actors is used to refer to actors that contribute in the generation and transmission of electricity service yet not directly involved in its distribution. While the significant connection of these actors to the distribution segment is clear, the nature of their responsibility and obligations in the partnership for distribution is unclear. It appears that distribution actors must take responsibilities and account for any failures by the generation and transmission actors. For instance when there are inadequacies in the amount of electricity generated (Interview 24, 2018)that affect the ability of the distribution partnership to deliver the service in the form and timing expected.

This issue is peculiar as it challenges the idea bundling of responsibilities as one of important tenets underlying the practice of PPPs. Specifically, despite the structural disintegration of the sector as discussed earlier, the interdependence arising from the nature of service provided by different units remained. In that case while the other actors in the value chain could affect the functioning of the partnership in important ways, the partnership have little control of the decision made by the other actors thus become victims and have to take responsibility for circumstances beyond their control. There has not been any scholarly identification of this kind of challenge. It is likely that this peculiar challenge arises from the government policy decision to unbundle the vertically integrated business units of generation, transmission and distribution into independent units with separate management which contradicts the notion of integration or the bundling of responsibilities in PPPs contracts (Saz-Carranza and Longo, 2012) in a way that the partners are responsible for the full breath of activities necessary for the provision of the service.

Further, the peculiarity of this issue is a result of the position of the partnership in the value chain of electricity service provision in Uganda. This PPP operates at the front end of the service delivery where there is a direct interface with the end user. As a front end service provider, regardless of the actor's level of control over the back end operations of the value chain partners, the front end must interface with the reaction of the end-users. In this case the responsible actor maybe 'shielded' by their position in the value and hence 'out of reach' of the end-users.

International Journal of Management and Applied Research, 2021, Vol. 8, No. 1 
The inevitable interdependences suggest the government policy to disintegrate the sector value chain and set up independent management for each business unit, as was the case in this sector, created units whose management control is systemically undermined by and dependent on others. Without control of the other value chain actors and their processes partnership become vulnerable and exposed to the extent of the other actors weaknesses. Theoretically, it is likely that because of the extant' studies focus on bundled PPP projects in less interdependent sectors, and limited attention on post contractual realities, this difficulty has not been apparent.

The third issue is the conflict in the identity and role of the public sector partner. The unclear identify and role played by the public sector partner in this phase of the partnership is apparent is the evidence. In this case, the existence of an independent sector regulator in the context of a contractual obligation between the parties representing the private and public sectors appears to undermine the identify and role of public sector representative. From an identity lens, it is for instance unclear whether the public sector partner ought to operate from a corporate or a regulatory view point in the partnership (Interview 23, 2018). In the similar vein, the evidence indicates incapacity to supervise the operator, non-adherence to the set reporting arrangements as well as limited due diligence by the public sector partners (Interview 23, 2018).In essence, an unclear perspective and largely inactive role of the public sector partner is revealed.

In the institutional context of this partnership, it is likely that this is resulting from the setup of the electricity sector and the contractual agreements made. Although the concession agreements provide for the oversight role of UEDCL, it does not provide for routine operational role besides 'being a landlord'. Instead the active role of supervising the routine delivery of the services is undertaken the regulatory authorities that interacts with the private partners in a regular and active manner. In addition, the public sector partner operates the distribution business in other zones outside those designated for the case study partnership. On one hand UEDCL has to operate as partner to UMEME and on the other it has to protect its own business interests against the same partner. This could suggest the conflict of interest particularly as it relates to commercial territorial conflicts. This evidently conflicting position potentially undermines the role of the public sector partners as it may become difficult to balance a partnership and competition.

While the nature of the role of the public sector in this PPP has been articulated by some authors (Jamali, 2004; Appuhami and Perera, 2016; Boyer, 2016), the focus has mainly been on understating these roles as either a partner or a regulator and mostly its role at the formative phase. In fact, in analyzing the management control mechanisms for minimizing risks in PPPs in Sri Lanka, Appuhami and Perera (2016) observed that at the formative stages, the government supportive role involved issuance of guarantees for debt capital as required by the international lending agencies facilitating unencumbered access to the other resources such as land through undertaking evacuation and resettlements. Such clarity is not explicit in this partnership where the government role manifests in different ways as a partner, as a regulator and as a competitor and this is role spread across a number of different public sector organisations. This makes it difficult to accurately pinpoint who the public sector

International Journal of Management and Applied Research, 2021, Vol. 8, No. 1 
partner in this particular partnership and what the scope of their roles and responsibilities is.

\subsection{The Regulatory and Contractual Control of the Partnership}

The arrangements for control of the partnership are another important theme at the post contractual phase. In this regard, the analysis reveals the primacy of three specific issues.

The first relate to changes in parameters by actors in the course of implementation. The evidence points to aspects such as conflict between the regulatory and the private partners as it relates to the definition, quality, quantity and pricing of investment made by the private operator (Interview 8, 2018; Interview 23, 2018; Interview 28, 2018), regulatory changes on performance targets and expectations already set out in the contractual agreements (Interview 24, 2018). In fact, with the passage of time since the contractual agreement, it appears that the perception among regulatory actors and the public sector partner is that the targets agreed up were insufficient and unambitious as they were premised on inaccurate information available and difficulty in predicting the sector performance at the time negotiation (Interview 28, 2018).

Parametric based contradictions among partners in the context partnership and during the operation of the partnership is not isolated to this case. Indeed it noted that working with the private sector challenges government staff to consider issues they are not accustomed to considering, such as the creation and oversight of key performance indicators (KPIs) (Boyer, 2016). As a result, the public sector typically faces positions of information asymmetry in respect to private partners (Appuhami and Perera, 2016). In this case, these could explain the public sector and regulatory actors post contractual perceptions of the insufficiency the parameters and agreed at the negotiation phase since this is the first among PPP negotiated and implemented in Uganda.

The second significant issue is the administration of regulatory processes. The conduct of processes for ensuring the measurement of and ascertainment of compliance with the set parameters for the partnership are important revelations. Specifically, how, when and who conducts the approval and verification processes for the investments made by the private partners (Interview 3, 2018; Interview 25, 2018; Interview 28, 2018).Equally, the difficulty with integration of multiple and diverse actor interests and input considerations in setting electricity tariff is significantly revealed (Interview 3, 2018; Interview 23, 2018).

In the context of this partnership, these processes are central and may remain points of contention for their centrality in determining the extent to that the interests of partnership can achieved. With more investments approved, the return for the private partner will be higher but at same time since full recovery of investments is based on tariff implies an increase on the service tariff may be unavoidable. Thus suggestion these will continue to be point of mutual interest and contention in which the application of the authority of single actor and/or opportunistic use of these processes in the interest of one partner may not be useful for the partnership. While investment verification and approval processes appear peculiar in this case, the centrality of tariff

International Journal of Management and Applied Research, 2021, Vol. 8, No. 1 
and the setting processes is noted issue in asset based infrastructure PPPs (Mouraviev, and Kakabadse, 2015; Sherratt et al., 2020).

The third issue is that the application of parallel regulatory and contractual tools of control. Specifically, the evidence reveals incidences in which the enactment or reenactment of regulatory rules appear to undermine the rules established in the negotiated contract between parties (Interview 28, 2018).It appears that in the absence of contractual remedy, the only room available to cause changes and influence the partnership is through the regulatory authority. This use of regulatory authority and instruments occasionally contradict the contractual provisions and is seen to undermine the authority of the contract as a central control instrument.

Indeed, in the context where institutions are meant to regulate actor's behaviours by dispersing power across the partnership (Bryson et al., 2017; Mouraviev and Kakabadse, 2015; Saz-Carranza and Longo, 2012; Vangen et al., 2015), the possibility of altering the power relationship between partners by utilizing non negotiated regulatory instruments is high and can exacerbate government opportunism.

This issue further suggests an important pre-contractual oversight of not scoping the authority of the regulator. As a result a necessity of two important yet contradictory conditions is created, a) the regulatory institution and instruments of the regulatory would have to be aligned to specific terms of the contract. But, if this were to happen then the sector wide-regulator would then be regulating different player the industry using different, b) the regulatory authority would have to apply standard terms and conditions for the entire industry -bringing to the fore the supremacy contest between the contract and regulatory rules evidence in this case.

\subsection{The Management of Emergent and Complex External Stakeholder Behaviour}

Further, the pre-eminence of emergent stakeholder expectations and perceptions is revealed in the evidence. Similar to the preceding theme, the experiences of individual actors reveals two specific issues: political actor interferences and service end-user expectations and perceptions.

Firstly, the apparent range of differences in political actor's interests and partnership interest appears to be an important driver of conflict in this partnership (Interview 23, 2018). In the context of case, political actors are considered as individuals or organisations with legislative and executive authority for public management at local and national levels. The exemplification of such differences is foregrounded in actions such as attempts to cause changes to the agreed commitments, processes and decisions of the partnership implementing actors (Interview 21, 2018) through legislative processes (World Bank, 2017; Interview 14, 2018; Interview 21, 2018; Interview 27, 2018) and individual political actor's directives (Interview 3, 2018; Interview 5, 2018; Interview 27, 2018; Interview 28, 2018).

As representative body, for instance, parliament has instituted parliamentary inquiries into the operations of the partners and particularly in to the operation of the private partner. The particular sourced of the parliamentary inquiries have been perceived role

International Journal of Management and Applied Research, 2021, Vol. 8, No. 1 
of the private partner in the increase of the tariff in the country. The conclusions of some of these inquiries suggest skewness to perceived source of the problem of tariff and also reinforce perception of contractual inequity. The quote below provides specific illustration:

Indications are that the reforms were done hurriedly. Due to the inadequate experience of most of the Government officials, the Government got saddled with poor contracting whereby contracts signed with developers, especially during the electricity crisis period, included unfair clauses that exaggerated costs, collective risks and provided excessive incentives e.g. for UMEME limited and other licensees/concessionaires. Attempts at amending the initial agreements did not address the anomalies (Report on Electricity Tariff Reduction chaired by Salem, 2009: 5)

The interference of political actors (individual and institutional) in the post contractual operations of PPPs has also been noted in some studies. Particularly, a number of studies have noted the challenge of political salience and 'political interest capture' (Birner and Wittmer, 2006; Johnston and Gudergan, 2007; van den Hurk and Verhoest, 2015). In analyzing the failure of the Cross City Tunnel toll way in Sydney, for instance, Johnston and Gudergan (2007) that failure in the PPP was occasioned by unforeseen political risks that occasioned the breakdown of the social contract. In particular they note that actors inevitably tend to bring their own established and different social legacies and organizational logics with them into the created PPP environment, in which case the potential for conflict becomes apparent because the project cannot proceed rationally as planned.

Similarly, Birner and Wittmer (2006) notes that 'political interest capture' can occur where the where political interests are not congruent with public interests. In this case it can be said the analysis substantially reveals some of these interest clashes where some political leaders facilitate the undermining of a policy arrangement to suit their narrow political interests with the electorate. In fact Birner and Wittmer (2006) note that such political interest capture can take many forms including tradeoff between short term goals and long-term goals, as well instances in which political decision makers have the incentive to act preferentially by seeking for preferential conditions for specific groups of people. Incidences of such preferential treatments have been illuminated in this study and with many empirical examples such as political leaders obstructing the execution of commercial process such as disconnection of electricity from defaulting client or leading public protests and demonstrations against the private operator and calling for termination of agreements without due attention to particular terms and conditions of the agreement informing the activities of the private operator.

Secondly, service end user behaviour exemplified prominently in the reaction and actions under taken in relation to payments for the service and expression of grievances. Specifically, in peculiar situations necessitating service tariff increments, the analysis particularly suggests a perception exists among end user of being exploited by the private operator (Interview 24, 2018) which appears to negatively impact on the payments compliance attitudes and exacerbates grievances (Interview 3, 2018)and escalation of complaints (Interview 28, 2018).

This aligns with observation in regard to confliction logics but also reinforces observations on opportunism, political interest capture and stakeholder opposition in

International Journal of Management and Applied Research, 2021, Vol. 8, No. 1 
the context of this interaction (Johnston and Gudergan, 2007; Spiller, 2013; van den Hurk and Verhoest, 2015). Spiller (2013) contends that the two important hazards for public and private interaction are the government and thirty-party opportunism. Spiller observes that these two interact to make regulatory processes and outcomes more rigid, formalistic, and prone to conflict than envisioned by relational contracting. Spiller (2013) argues that third party opportunism thrives in an environment of political contestability and fragmentation in open access states, where oversight bodies and external stakeholders expect to challenge decisions. This is explicit in this case with the revealed behaviour political actors and end-users (Stafford and Stapleton, 2017).

In addition, the end user behaviour illustrated suggests and brings to question the affordability of the service. In particular, none payment of billed electricity and access to service through illegal connection could be resulting from the inability of the enduser to pay for the electricity service. With government reduced in the subsidization the reality of the cost of electricity is felt directly by the end-users and brings to the fore the rampant incapacity to afford the service. This important issue influences the nature of interrelation between the actors in partnership (Saz-Carranza and Longo, 2012) and the extent of project quality (Sheratt et al., 2020).

Further, the commercial approach to end users as customer other than as citizen appears requires more adaptation. With the citizenry used to public goods and service offered through taxes and with very highly subsided costs, private delivery and management of public goods and services is new phenomenon. In other words the adaptation to the private provision of the public is still low and the analysis suggests that many end-users are yet to accept and get used to the culture. This is probably an expected challenge considering the model of PPPs in service provisions is new in Uganda and has never be applied to common use services such as electricity.

In fact, in illuminating the Swiss context, Hofmeister and Borchert (2004) posited that more contested an area of public service is the more PPP will face opposition. They noted the traditional 'public markets' such as broadcasting or postal services or electricity or waste management as some of the examples. They noted that in such contexts of 'high politics', that is, 'when strategic decisions about policy alternatives are necessary, PPP may fail completely as long as the dominant political thinking cannot be changed' (Hofmeister and Borchert, 2004:224).

\section{Conclusion and implications}

This paper set out to identify and organize important issues at the post-contractual phase of Public Private Partnerships and generate their implications for policy and practice. In that regard, this paper has foregrounded and placed into broader governance perspective three fundamental themes and eight specific issues important at the post contractual.

As a whole, firstly, this paper has showed the conflated the role of the state in the context of public private partnership in setting existing independent sector regulations. The revelations have showed contradictions in which the regulatory role of the state to protect public interest is challenged by its corporate responsibility as partner in

International Journal of Management and Applied Research, 2021, Vol. 8, No. 1 
commercial relationship involving private sector actors. Secondly, the findings have demonstrated the ongoing institutional supremacy contests that reinforce the notion of contractual incompleteness and further suggest the undermined authority of the contractual agreement as a central instrument to distribute authority and create cooperative power among actors. The inherent incompleteness of contract indicates creative utilisation the institutional gaps to reapportion authority and apply alternative power sources to shape the course of the partnership fashioning power asymmetries among actors. Thirdly, the findings have showed contradictory stakeholder interactions, particularly between the partners and the different categories of stakeholders that suggest significant the information asymmetries.

These findings have important implications for practice and policy courses of actions. Firstly, filling the institutional gaps, deliberately, inadvertently and/or inevitably, left open at the contracting phase in a way that guards against opportunism and creation of power asymmetries is important for both public and private actors. In that regard, it is important that the gap filling processes and measures mirror the initial negotiation processes by being concerted and inclusive in order not to undermine the rationality of the partnership. Secondly, the stakeholder opposition demonstrated by end-users behaviour, the apparent institutional contests, and government role conflation suggest a necessity of multi-stakeholder and multilevel education as well as institutional reviews to enhance capacity and readiness for the modality public private partnership. Thirdly, the policy necessity to clearly demarcate the scope of control for regulatory and contractual instruments is apparent. Harmonizing control institutions by explicitly scoping the realms of influence and detailing the nature of expected complementation between the regulatory instruments and contractual agreements work complementary is critical to help actors navigate the distractive contestation from questions of institutional supremacy.

The analysis of this case has led to important conclusions and generation of implications, some not dissimilar to governance issues suggested in different national jurisdictions and are consistent with general claims in the literature about PPPs, but some limitations that need to be taken into account are acknowledged. First, a particular model of public private partnership of a concession is utilised which may limit the perspective to its peculiar characteristics. Secondly, one project from a specific sector and a specific national context that underwent important policy reforms in the period preceding the formation of this partnership is utilised. Third, interviews required retrospective experiences of actors, some for as long as fourteen years ago, (although mostly corroborated by documentary evidence), may be affected by any memory losses of the interviewees. Fourth, because the findings are based on a qualitative inquiry, there is a need to further assess whether the observations are valid for other sector and contexts with different political, legal and regulatory arrangements.

It is this papers contention that the findings of this study may mirror the realities of many developing countries whose adoption of PPPs was highly influenced by the neoliberal ideals and whose practical implementation was supported in a homogenous way by multilateral lending agencies such as the World Bank. That notwithstanding,

International Journal of Management and Applied Research, 2021, Vol. 8, No. 1 
we suggest that a comparative study of projects fashioned in different PPP models and in different sectors maybe useful.

\section{References}

1. Appuhami, R. and Perera, S. (2016), "Management controls for minimising risk in public-private partnerships in a developing country: Evidence from Sri Lanka", Journal of Accounting and Organizational Change, Vol. 12, No. 3, pp. 408-431. https://doi.org/10.1108/JAOC-10-2013-0075

2. Birner, R. and Wittmer, H. (2006), "Better public sector governance through partnership with the private sector and civil society: the case of Guatemala's forest administration", International Review of Administrative Sciences, Vol. 72, No. 4, pp. 459-472. https://doi.org/10.1177\%2F0020852306070077

3. Bovaird, T. (2004), "Public-private partnerships: from contested concepts to prevalent practice", International review of administrative sciences, Vol. 70, No. 2, pp. 199-215. https://doi.org/10.1177\%2F0020852304044250

4. Boyer, E. J. (2016), "Identifying a knowledge management approach for publicprivate partnerships", Public Performance and Management Review, Vol. 40, No. 1, pp. 158-180. https://doi.org/10.1080/15309576.2016.1204928

5. Brinkerhoff, D. W. and Brinkerhoff, J. M. (2011), "Public-private partnerships: Perspectives on purposes, publicness, and good governance", Public Administration and Development, Vol. 31, No. 1, pp. 2-14. https://doi.org/10.1002/pad.584

6. Bryson, J.; Sancino, A.; Benington, J. and Sorensen, E. (2017), "Towards a multiactor theory of public value co-creation", Public Management Review, Vol. 19, No. 5, pp. 640-654. https://doi.org/10.1080/14719037.2016.1192164

7. Chung, D. (2009), "Developing an analytical framework for analysing and assessing public-private partnerships: a hospital case study", The Economic and Labour Relations Review, Vol. 19, No. 2, pp. 69-90. https://doi.org/10.1177\%2F103530460901900206

8. Grimsey, D. and Lewis, M. K. (2002), "Evaluating the risks of public private partnerships for infrastructure projects", International Journal of Project Management, Vol. 20, No. 2, pp. 107-118. https://doi.org/10.1016/S02637863(00)00040-5

9. Heuer, M. (2011), "Ecosystem Cross-Sector Collaboration: Conceptualizing an Adaptive Approach to Sustainability Governance", Business Strategy and the Environment, Vol. 20, No. 4, pp. 211-221. https://doi.org/10.1002/bse.673

International Journal of Management and Applied Research, 2021, Vol. 8, No. 1 
10. Hodge, G. and Greve, C. (2010), "Public-Private Partnerships: Governance Scheme or Language Game?", Australian Journal of Public Administration, Vol. 69, S1, pp. S8-S22. https://doi.org/10.1111/j.1467-8500.2009.00659.x

11. Hodge, G. A. and Greve, C. (2007), "Public-private partnerships: an international performance review", Public administration review, Vol. 67, No. 3, pp. 545-558. https://doi.org/10.1111/j.1540-6210.2007.00736.x

12. Hofmeister, A. and Borchert, H. (2004), "Public-private partnerships in Switzerland: Crossing the bridge with the aid of a new governance approach", International Review of Administrative Sciences, Vol. 70, No. 2, pp. 217-232. https://doi.org/10.1177\%2F0020852304044251

13. Jamali, D. (2004), "Success and failure mechanisms of public private partnerships (PPPs) in developing countries: Insights from the Lebanese context", International Journal of Public Sector Management, Vol. 17, No. 5, pp. 414-430. https://doi.org/10.1108/09513550410546598

14. Johnston, J. and Gudergan, P. S. (2007), "Governance of public-private partnerships: lessons learnt from an Australian case?", International Review of Administrative Sciences, Vol. 73, No. 4, pp. 569-582. https://doi.org/10.1177\%2F0020852307083459

15. Klijn, E. H. And Teisman, G. (2000), "Managing Public-Private Partnerships: Influencing Processes and Institutional Context of Public-Private Partnerships", In: van Heffen O., Kickert W.J.M., Thomassen J.J.A. (eds), Governance in Modern Society, Vol. 4. Dordrecht: Springer. https://doi.org/10.1007/978-94-015-94868_16

16. Marcelo, D.; House, S.; Mandri-Perrott, C.; Schwartz J. (2017), Do Countries Learn from Experience in Infrastructure PPP? PPP Practice and Contract Cancellation, Washington DC: World Bank, https://doi.org/10.1596/1813-94508054

17. Miles, M. B. and Huberman, M. (1994) Qualitative data analysis: An expanded sourcebook. $2^{\text {nd }}$ ed. Thousand Oaks, CA: Sage Publication.

18. Mouraviev, N. and Kakabadse, N. K. (2015), "Legal and regulatory barriers to effective public-private partnership governance in Kazakhstan”, International Journal of Public Sector Management, Vol. 28, No. 3, pp. 181-197. https://doi.org/10.1108/IJPSM-09-2014-0116

19. Neale, P.; Thapa, S. and Boyce, C. (2006), Preparing a case study: A guide for designing and conducting a case study for evaluation input. Massachusetts: Pathfinder international.

20. Opawole, A. and Jagboro, G. O. (2017), "Factors affecting the performance of private party in concession-based PPP projects in Nigeria", Journal of

International Journal of Management and Applied Research, 2021, Vol. 8, No. 1 
Engineering, Design and Technology, Vol. 15, No. 1, pp. 44-57. https://doi.org/10.1108/JEDT-09-2015-0058

21. Ramiah, I. and Reich, M. R. (2006), "Building effective public-private partnerships: Experiences and lessons from the African Comprehensive HIV/AIDS Partnerships (ACHAP)", Social Science and Medicine, Vol. 63, No. 2, pp. 397408. https://doi.org/10.1016/j.socscimed.2006.01.007

22. Reeves, E. (2013), "The not so good, the bad and the ugly: over twelve years of PPP in Ireland", Local Government Studies, Vol. 39, No. 3, pp. 375-395. https://doi.org/10.1080/03003930.2013.781023

23. Sabry, M. I. (2015), "Good governance, institutions and performance of public private partnerships", International Journal of Public Sector Management, Vol. 28, No. 7, pp. 566-582. https://doi.org/10.1108/IJPSM-01-2015-0005

24. Salem, S. (2009), Report on Electricity Tariff Reduction. Uganda: Electricity Tariff Committee.

25. Saz-Carranza, A. and Longo, F. (2012), "Managing competing institutional logics in public-private joint ventures", Public Management Review, Vol. 14, No. 3, pp. 331-357. https://doi.org/10.1080/14719037.2011.637407

26. Griffith-Jones, S. and Bhattacharya, A. (2001), Developing Countries and the Global Financial System, The Commonwealth Secretariat. https://doi.org/10.14217/9781848597488-13-en

27. Sherratt, F.; Sherratt, S. and Ivory, C. (2020), "Challenging complacency in construction management research: the case of PPPs", Construction Management and Economics, Vol. 38, No. 12, pp. 1086-1100, https://doi.org/10.1080/01446193.2020.1744674

28. Spiller, P. T. (2013), "Transaction cost regulation", Journal of Economic Behavior and Organization, Vol. 89, pp. 232-242. https://doi.org/10.1016/j.jebo.2012.03.002

29. Stafford, A. and Stapleton, P. (2017), "Examining the Use of Corporate Governance Mechanisms in Public-Private Partnerships: Why Do They Not Deliver Public Accountability?", Australian Journal of Public Administration, Vol. 76, No. 3, pp. 378-391. https://doi.org/10.1111/1467-8500.12237

30. Trebilcock, M. and Rosenstock, M. (2015), "Infrastructure Public-Private Partnerships in the Developing World: Lessons from Recent Experience", The Journal of Development Studies, Vol. 51, No. 4, pp. 335-354. https://doi.org/10.1080/00220388.2014.959935

31. Van den Hurk, M. and Verhoest, K. (2015), "The governance of public-private partnerships in sports infrastructure: Interfering complexities in Belgium",

International Journal of Management and Applied Research, 2021, Vol. 8, No. 1 
International Journal of Project Management, Vol. 33, No. 1, pp. 201-211. https://doi.org/10.1016/j.ijproman.2014.05.005

32. Van Gestel, K., Willems, T., Verhoest, K., Voets, J. and Van Garsse, S. (2014), "Public-private partnerships in Flemish schools: a complex governance structure in a complex context", Public Money and Management, Vol. 34, No. 5, pp. 363-370. https://doi.org/10.1080/09540962.2014.945808

33. Vangen, S., Hayes, J. P. and Cornforth, C. (2015), "Governing Cross-Sector, InterOrganizational Collaborations", Public Management Review, Vol. 17, No. 9, pp. 1237-1260. https://doi.org/10.1080/14719037.2014.903658

34. Velotti, L., Botti, A. and Vesci, M. (2012), "Public-private partnerships and network governance: What Are the Challenges?", Public Performance and Management Review, Vol. 36, No. 2, pp. 340-365. https://doi.org/10.2753/PMR1530-9576360209

35. Vurro, C., Dacin, M. T. and Perrini, F. (2010), "Institutional Antecedents of Partnering for Social Change: How Institutional Logics Shape Cross-Sector Social Partnerships", Journal of Business Ethics, Vol. 94, No. 1, pp. 39-53. https://doi.org/10.1007/s10551-011-0778-0

36. Weihe, G. (2008), "Public-private partnerships and public-private value tradeoffs", Public Money and Management, Vol. 28, No. 3, pp. 153-158. https://doi.org/10.1111/j.1467-9302.2008.00637.x

37. Word Bank (1994), Governance: the Banks Experience. Washington DC: World Bank [Online] Available from:

http://documents.worldbank.org/curated/en/711471468765285964/pdf/multiOpage. pdf [Accessed on 15 January 2021].

38. World Bank (2017), Infrastructure finance deficit: Can public-private partnerships fill the gap? [Online] Available from:

https://www.worldbank.org/en/country/uganda/brief/infrastructure-finance-deficitcan-public-private-partnerships-fill-the-gap [Accessed on 15 January 2021].

39. World Bank (2018), 2017 Energy Sector: Private Participation in Infrastructure. Washington DC: World Bank [Online] Available from: https://openknowledge.worldbank.org/handle/10986/31037 [Accessed on 12 January 2021].

40. World Bank (2019), PPI Data. [Online] Available from: https://ppi.worldbank.org/en/ppidata [Accessed on 12 January 2021].

41. Yin, R. K. (2011), Applications of case study research. California: Sage Publication.

International Journal of Management and Applied Research, 2021, Vol. 8, No. 1 


\section{Appendix 1: List of Interview Participants}

\begin{tabular}{|c|c|c|}
\hline Position at time of interview & Category & Code \\
\hline $\begin{array}{l}\text { Investment Officer, International } \\
\text { Finance Corporation- Subsaharan } \\
\text { Africa }\end{array}$ & Independent consultancy & Interview 1 \\
\hline $\begin{array}{l}\text { Managing Director, Mott Macdonald, } \\
\text { Transaction Advisory firm }\end{array}$ & Independent consultancy & Interview 2 \\
\hline Managing Director, UMEME (SPV) & Private sector partner & Interview 3 \\
\hline $\begin{array}{l}\text { Regulatory Financial Controller, } \\
\text { UMEME (SPV) }\end{array}$ & Private sector partner & Interview 4 \\
\hline Economist, UMEME (SPV) & Private sector partner & Interview 5 \\
\hline $\begin{array}{l}\text { Engineering Consultant/Ex Projects } \\
\text { Manager/Quality Assurance Manager, } \\
\text { UMEME (SPV) }\end{array}$ & Private sector partner & Interview 6 \\
\hline $\begin{array}{l}\text { Private Legal consultant/Ex Director } \\
\text { Legal Privatisation Unit, Ministry of } \\
\text { Finance Planning and Economic } \\
\text { Development }\end{array}$ & $\begin{array}{l}\text { Government department and } \\
\text { agencies }\end{array}$ & Interview 7 \\
\hline $\begin{array}{l}\text { Ex minister of Energy and Mineral } \\
\text { Resources }\end{array}$ & $\begin{array}{l}\text { Government department and } \\
\text { agencies }\end{array}$ & Interview 8 \\
\hline $\begin{array}{l}\text { Presidential Advisor on Oil and Gas/Ex } \\
\text { Permanent secretary - Ministry of } \\
\text { Energy and Mineral resources }\end{array}$ & $\begin{array}{l}\text { Government department and } \\
\text { agencies }\end{array}$ & Interview 9 \\
\hline Deputy Speaker of Parliament & $\begin{array}{l}\text { Government department and } \\
\text { agencies }\end{array}$ & Interview 10 \\
\hline $\begin{array}{l}\text { Ag. Director, Energy Resources } \\
\text { Development, Ministry of Energy and } \\
\text { Mineral Resources }\end{array}$ & $\begin{array}{l}\text { Government department and } \\
\text { agencies }\end{array}$ & Interview 11 \\
\hline Minister of state for Energy & $\begin{array}{l}\text { Government department and } \\
\text { agencies }\end{array}$ & Interview 12 \\
\hline $\begin{array}{l}\text { Ag. Director, Private Partnership Unit } \\
\text { (PPPU), Ministry of Finance Planning } \\
\text { and Economic Development }\end{array}$ & $\begin{array}{l}\text { Government department and } \\
\text { agencies }\end{array}$ & Interview 13 \\
\hline $\begin{array}{l}\text { Ex Director, Privatisation Unit, } \\
\text { Ministry of Finance Planning and } \\
\text { Economic Development }\end{array}$ & $\begin{array}{l}\text { Government department and } \\
\text { agencies }\end{array}$ & Interview 14 \\
\hline $\begin{array}{l}\text { Senior Communication Officer, } \\
\text { Privatization Unit, Ministry of Finance } \\
\text { Planning and Economic Development }\end{array}$ & $\begin{array}{l}\text { Government department and } \\
\text { agencies }\end{array}$ & Interview 15 \\
\hline $\begin{array}{l}\text { Director, Privatisation Unit, Ministry } \\
\text { of Finance Planning and Economic } \\
\text { Development }\end{array}$ & $\begin{array}{l}\text { Government department and } \\
\text { agencies }\end{array}$ & Interview 16 \\
\hline $\begin{array}{l}\text { Manager, Off Grid, Rural } \\
\text { Electrification Agency }\end{array}$ & $\begin{array}{l}\text { Government department and } \\
\text { agencies }\end{array}$ & Interview 17 \\
\hline $\begin{array}{l}\text { Chief Finance Officer, Uganda } \\
\text { Electricity Distribution Company } \\
\text { Limited }\end{array}$ & Public sector Partner & Interview 18 \\
\hline $\begin{array}{l}\text { Head strategy, Uganda National Roads } \\
\text { Authority }\end{array}$ & $\begin{array}{l}\text { Government department and } \\
\text { agencies }\end{array}$ & Interview 19 \\
\hline Engineer, Uganda National Roads & Government department and & Interview 20 \\
\hline
\end{tabular}

International Journal of Management and Applied Research, 2021, Vol. 8, No. 1 
Understanding Post Contractual Turbulence in Public Private Partnerships: Themes and Issues

\begin{tabular}{|l|l|c|}
\hline Authority & agencies & \\
\hline $\begin{array}{l}\text { Private Energy consultant/Ex. } \\
\text { Managing Director, Electricity } \\
\text { Regulatory Authority }\end{array}$ & Regulation & Interview 21 \\
\hline $\begin{array}{l}\text { Director, Economic Regulation, } \\
\text { Electricity Regulatory Authority }\end{array}$ & Regulation & Interview 22 \\
\hline $\begin{array}{l}\text { Manager, Economic Regulation and } \\
\text { Research, Electricity Regulatory } \\
\text { Authority }\end{array}$ & Regulation & Interview 23 \\
\hline $\begin{array}{l}\text { Private legal practice/ Ex Legal } \\
\text { Secretary, Electricity Regulatory } \\
\text { Authority }\end{array}$ & Regulation & Interview 24 \\
\hline $\begin{array}{l}\text { Private Engineering consultant/ Ex } \\
\text { Director, Technical Regulation, } \\
\text { Electricity Regulatory Authority }\end{array}$ & Regulation & Interview 25 \\
\hline $\begin{array}{l}\text { Manager, Legal and compliance, } \\
\text { Electricity Regulatory Authority }\end{array}$ & Regulation & Interview 26 \\
\hline $\begin{array}{l}\text { Manager, Pricing, Electricity } \\
\text { Regulatory Authority }\end{array}$ & Regulation & Interview 27 \\
\hline $\begin{array}{l}\text { Manager, Corporate Planning, } \\
\text { Electricity Regulatory Authority }\end{array}$ & Regulation & Interview 28 \\
\hline
\end{tabular}

International Journal of Management and Applied Research, 2021, Vol. 8, No. 1 